Hydrol. Earth Syst. Sci., 14, 223-237, 2010

www.hydrol-earth-syst-sci.net/14/223/2010/

(C) Author(s) 2010. This work is distributed under

the Creative Commons Attribution 3.0 License.

\title{
Modelling the inorganic nitrogen behaviour in a small Mediterranean forested catchment, Fuirosos (Catalonia)
}

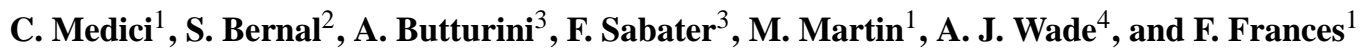 \\ ${ }^{1}$ Department of Hydraulic and Environmental Engineering, Polytechnic University of Valencia, Spain \\ ${ }^{2}$ Centre d'Estudis Avancats de Blanes (CEAB-CSIC), Girona, Spain \\ ${ }^{3}$ Department of Ecology, University of Barcelona, Spain \\ ${ }^{4}$ Aquatic Environments Research Centre, University of Reading, Reading, UK
}

Received: 29 July 2009 - Published in Hydrol. Earth Syst. Sci. Discuss.: 4 September 2009

Revised: 12 January 2010 - Accepted: 23 January 2010 - Published: 8 February 2010

\begin{abstract}
The aim of this work was to couple a nitrogen $(\mathrm{N})$ sub-model to already existent hydrological lumped (LU4$\mathrm{N}$ ) and semi-distributed (LU4-R-N and SD4-R-N) conceptual models, to improve our understanding of the factors and processes controlling nitrogen cycling and losses in Mediterranean catchments. The $\mathrm{N}$ model adopted provides a simplified conceptualization of the soil nitrogen cycle considering mineralization, nitrification, immobilization, denitrification, plant uptake, and ammonium adsorption/desorption. It also includes nitrification and denitrification in the shallow perched aquifer. We included a soil moisture threshold for all the considered soil biological processes. The results suggested that all the nitrogen processes were highly influenced by the rain episodes and that soil microbial processes occurred in pulses stimulated by soil moisture increasing after rain. Our simulation highlighted the riparian zone as a possible source of nitrate, especially after the summer drought period, but it can also act as an important sink of nitrate due to denitrification, in particular during the wettest period of the year. The riparian zone was a key element to simulate the catchment nitrate behaviour. The lumped LU4-N model (which does not include the riparian zone) could not be validated, while both the semi-distributed LU4-R-N and SD4-R$\mathrm{N}$ model (which include the riparian zone) gave satisfactory results for the calibration process and acceptable results for the temporal validation process.
\end{abstract}

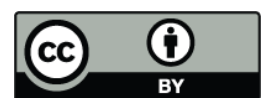

Correspondence to: C. Medici (chme1@ doctor.upv.es)

\section{Introduction}

Nitrogen is present in both terrestrial and aquatic ecosystems and research is needed to understand its storage, transportation and transformations in river catchments world-wide because of its importance in controlling plant growth and freshwater trophic status (Vitousek et al., 2009; Chu et al., 2008; Schlesinger et al., 2006; Ocampo et al., 2006; Green et al., 2004; Arheimer et al., 1996). Numerous mathematical models have been developed to describe the nitrogen dynamics in cool temperate river-systems, but further work is needed to understand and model the main processes controlling the nitrogen cycle in Mediterranean and semi-arid ecosystems since these systems are not well understood (Gelfand et al., 2008; Bernal et al., 2005; Avila et al., 1995; Wade et al., 2005). Mediterranean catchments are characterized by a complex hydrological behaviour that causes high inter and intra-annual variability in flow (Gallart et al., 2002). Consequently, models developed for temperate climates generally fail when applied to Mediterranean catchments (Bernal et al., 2004). Mediterranean ecosystems are subjected to severe drought periods followed by intense rainfall events, which produce alternate dry and humid conditions that influence the soil microbial activity (Austin et al., 2004; Reynolds et al., 2004; Schwinning et al., 2004b). Models based on a representation of temperate climates do not represent this rapid transition from dry to wet periods well. Birch $(1959,1960$, and 1964) was one of the first to characterize the impacts of soil drying and wetting cycles on mineralization and nitrification, demonstrating that rapid mineralization follows rewetting of dry soil and that in continuously moist conditions there is a release of nitrogen, much of it as nitrate. Many

Published by Copernicus Publications on behalf of the European Geosciences Union. 
other authors stressed the influence that wet-dry cycles have on microbial biomass (Van Gestel et al., 1993), denitrification (Mummey et al., 1994; Peterjhon and Schlesinger, 1991) and ammonia volatilization (Heckathorn and Delucia, 1995). Schiwinning et al. (2004a, b) spoke about a "pulse dynamic" in arid and semi-arid ecosystems, considering the rainfall inputs to a dry soil as triggers of a cascade of biogeochemical and biological transformations. According to Schiwinning et al. (2004a, b), precipitation applied to a dry soil surface creates a pulse of soil moisture that can be characterized by the depth to which soil water potentials are elevated to levels that promote biological activity and the length of time over which water potentials remain at biologically relevant levels. Intermittent streams and their associated riparian zone have been highlighted as "hot spots" for biogeochemical processes in arid and semi-arid regions (McIntyre et al., 2009). Bernal et al. (2007) suggested that Mediterranean riparian soils act as source or sink of dissolved nitrogen depending on the period of the year, mainly due to contrasting soil moisture condition between the dry and the wet period. Moreover, Butturini et al. (2003) suggested the unsaturated riparian soil of the Fuirosos catchment, a small intermittent Mediterranean stream in Catalonia (Spain), as a possible source of nitrate, especially after the summer drought, which can be rapidly mobilized due to the formation of a rising riparian groundwater table into the unsaturated upper soil layer adjacent to the stream channel. The nitrogen dynamics of the Fuirosos catchment were analysed previously with the process-based Integrated Catchment Model of Nitrogen (INCA-N) model (Whitehead et al., 1998; Wade et al., 2002; Bernal et al., 2004). INCA-N was developed for temperate regions and has been demonstrated to simulate properly the hydrology and nitrogen dynamics observed in these types of ecosystems (Wade et al., 2004). The model gave unsatisfactory result for the Fuirosos catchment suggesting that key processes were missing (Bernal et al., 2004). The present research aims to develop a new model to represent the inorganic nitrogen response in Mediterranean catchments using INCA$\mathrm{N}$ as a basis for the equations implemented, but including additional mechanisms to take into account the ideas and results pointed out before and obtained in previous studies in semi-arid and Mediterranean catchments. Namely, these new elements are: biological thresholds responses to soil moisture in order to reproduce the pulse dynamic observed in such environment; a specific function for the soil moisture correction factor for the mineralization process; nitrification and denitrification processes associated to the shallow perched water table and finally, the introduction of a riparian zone compartment. The nitrogen model scheme developed in this study was coupled to already existent hydrological conceptual models previously applied to the Fuirosos catchment (Medici et al., 2008).

\section{Study site}

The Fuirosos catchment (latitude $41^{\circ} 42^{\prime} \mathrm{N}$, longitude $2^{\circ} 34^{\prime} \mathrm{E}$ ) is located in the northern slopes of Catalan Littoral Range, near Barcelona (Spain) and it is a tributary of the Tordera River. The drainage area of Fuirosos is approximately $13 \mathrm{~km}^{2}$ and the altitude ranges from 50 to $770 \mathrm{~m}$ a.s.l. (Fig. 1). The catchment is almost pristine, the predominant land cover being undisturbed forest; there is little agricultural activity and no urban areas. Within the catchment, there are four small reservoirs for human and cattle water supply (Fig. 1). This water consumption can be considered insignificant during the study period. The storage volume of these reservoirs ranges approximately from 5000 to $18000 \mathrm{~m}^{3}$. The climate is typically Mediterranean, with temperature ranging from a monthly mean of $3{ }^{\circ} \mathrm{C}$ in January to $24^{\circ} \mathrm{C}$ in August. Winter temperatures below $0{ }^{\circ} \mathrm{C}$ are infrequent. During the observed period (from October 1999 to June 2003), the mean annual precipitation at Fuirosos was approximately $750 \mathrm{~mm}$. The first hydrological year (1999/2000) was the driest of the four considered in this study (annual precipitation $454 \mathrm{~mm}$ ) and the third (2001/2002) was the wettest (annual precipitation $850 \mathrm{~mm}$ ). The mean annual potential evapotranspiration (PET) computed with the Penman equation considering the period from October 1999 to June 2003, was approximately $975 \mathrm{~mm}$. The observed number of consecutive days during which the Fuirosos stream was completely dry reached values of 76 (summer 2000) and 98 (summer 2001). The predominant rock type in the Fuirosos catchment is leucogranite (50.9\%). Other rock types include granodiorite (21.1\%) and sericitic schists (23.5\%) (IGME, 1983; Fig. 1). At the valley bottom there is an alluvial zone, where a well-developed riparian area flanks the Fuirosos stream channel. The forest covers the $90 \%$ of the total catchment area where perennial cork oak (Quercus suber) and pine tree (Pinus halapensis and Pinus pinaster) predominate. However, at the valley headwaters, mixed deciduous woodland of chestnut (Castanea sativa), hazel (Corylus avellana) and oak (Quercus pubescens) prevail. The discharge was measured from 13 October 1999 to 30 June 2003. Daily streamwater nitrate $\left(\mathrm{NO}_{3}\right)$ concentrations were also measured in water samples taken from the catchment outlet during the period from October 1999 to April 2003 and daily ammonium $\left(\mathrm{NH}_{4}\right)$ concentrations were also measured during the period from January 2001 to August 2002. For a compete description of the Fuirosos chemical water analyses see Bernal et al. $(2004,2005)$.

\section{N-model description}

The hydrological behaviour of the Fuirosos catchment has been successfully modelled previously (Medici et al., 2008). A key result of this previous study is that the perceptual model including four different catchment hydrological 


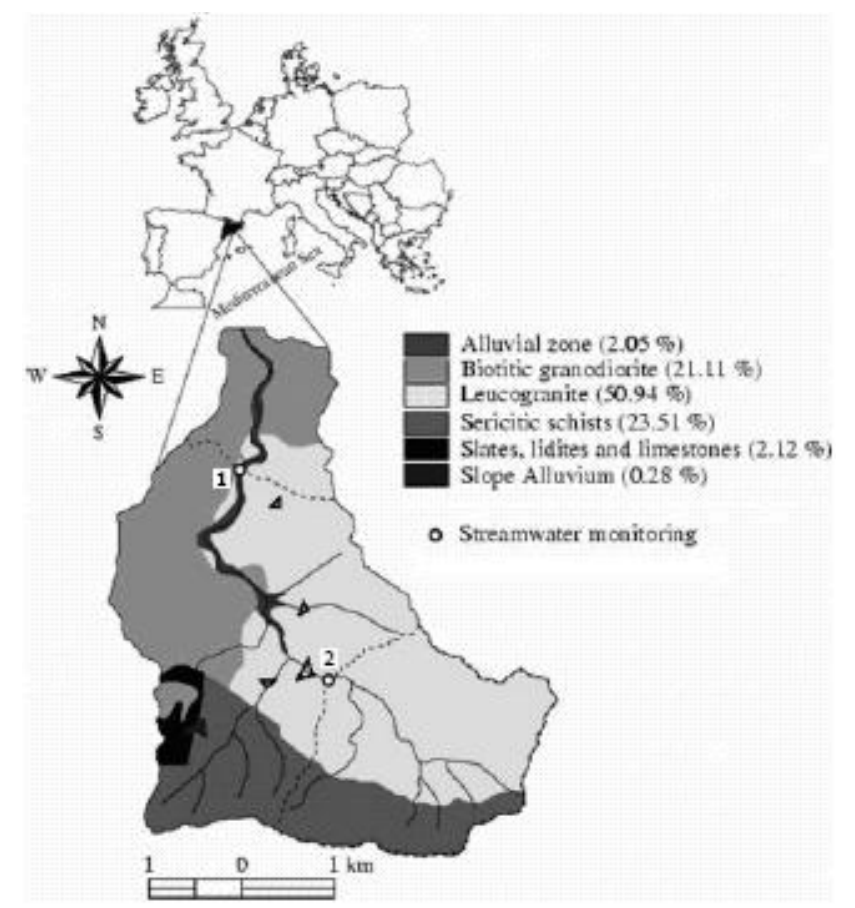

Fig. 1. Geographical location of the Fuirosos catchment (Catalonia, NE Spain). Lithological units are shown in different shadings. The little triangles represent the four small reservoirs present in the catchment.

responses (direct flow, interflow, quick and slow base flow) is the most suitable to simulate the discharge at Fuirosos. The initial lumped conceptual model proposed (LU4) was developed into a semi-distributed form (SD4-R) in which the spatial variability of the evapotranspiration according to the vegetation cover and the local aspect was considered. In the final semi-distributed structure of the hydrological model (which gave a best fit of 0.78 in term of Nash \& Sutcliffe index) an additional conceptual store representing the riparian zone was included, as well as the four reservoirs present in the catchment. In the current work, the previous cited models were extended to include processes representing the inorganic nitrogen cycle to simulate the nitrate and ammonium concentration observed in the Fuirosos stream. Therefore, the progressive perceptual approach adopted led from an initial lumped structure (LU4-N) to a very simple semidistributed one (LU4-R-N) that included the riparian tank along with the four small reservoirs and eventually to a more complex semi-distributed one (SD4-R-N) that included the riparian zone, the four reservoirs as well as catchment spatial variability to some extent. The first approach to simulate the transport, storage and transformations of nitrogen in the terrestrial and aquatic components of the catchment was done using the lumped hydrological (LU4) model as a basis. The LU4-N model integrates hydrology, soil and shallow aquifer $\mathrm{N}$ processes, and simulates daily $\mathrm{NO}_{3}-\mathrm{N}$ and $\mathrm{NH}_{4}-\mathrm{N}$ concentrations in the stream. The soil nitrogen cycle conceptual model includes the mineralization process and nonbiological nitrate fixation modelled using zero order kinetic. The processes of nitrification, ammonium bacterial immobilisation, ammonium and nitrate soil plant uptake, abiotic absorption and denitrification are included and represented using first order kinetic. The total number of parameter to be calibrated for the LU4-N model is 28 of which 9 are for the rainfall-runoff sub-model and 19 for the N sub-model. A perceptual model which shows the key nitrogen stores and pathways is presented in Fig. 2. At present, the only source of $\mathrm{N}$ is atmospheric deposition as this is the main input of nitrogen in the catchment but other anthropogenic sources could be included in future versions if required. For the deposition, the estimated values obtained by Rodá et al. (2002, after Bernal et al., 2004) were used. Namely: the wet deposition of inorganic $\mathrm{N}$ was $5.7 \mathrm{~kg} \mathrm{~N} \mathrm{ha}^{-1} \mathrm{yr}^{-1}$ (52\% as ammonium and $48 \%$ as nitrate), while the dry deposition of inorganic $\mathrm{N}$ was $9.2 \mathrm{~kg} \mathrm{~N} \mathrm{ha}^{-1} \mathrm{yr}^{-1}$ (45\% as ammonium and $55 \%$ as nitrate). The model equations were written in terms of $\mathrm{N}$ mass and water volume and a daily time step was adopted. The equations were solved sequentially (i.e. for the soil ammonium cycle: first of all mineralization, secondly immobilization then plant uptake and finally nitrification) and it was verified, taking into account several different sequences, that the particular one adopted did not significantly affect the model results. In both shallow and deeper aquifer, $\mathrm{N}$ uptake associated with the transpiration flux is assumed to occur, which depends on the simulated $\mathrm{NH}_{4}$ and $\mathrm{NO}_{3}$ concentration in each aquifer, on the amount of water transpirated by plants and finally on the annual maximum solute uptake. All the soil processes are adjusted by a soil moisture factor $\left(S_{1}\right.$ Process $)$ to represent the moisture control on bacterial processes and are temperature dependent (Whitehead et al., 1998; Wade et al., 2002). Moreover, a different soil moisture threshold $(U)$ has been introduced for each soil process to determine activation. The concept of a threshold response is not new in arid land ecology (Reynolds et al., 2004; Schwinning et al., 2004a). Traditionally this concept has been related with the ecosystem primary production, though Schwinning and Sala (2004) generalized the threshold paradigm to a wide range of ecosystem processes. In fact, they suggested that the hierarchy of pulse events has a corresponding hierarchy of ecological responses that is determined by the ability of organism to utilize soil moisture pulses of different duration, infiltration depths and soil water potential. As a matter of example, the mineralization processes is described as:

$M_{\mathrm{NH}_{4} \_ \text {Miner }}(t)=K_{\text {Miner }} \cdot S_{1 \_ \text {Miner }}(t) \cdot T F$

where: $M_{\mathrm{NH}_{4} \text {-Miner }}$ is the ammonium mineralized mass $\left(\mathrm{kg} \mathrm{ha}^{-1} \mathrm{day}^{-1}\right)$ in a time step; $K_{\text {miner }}$ is mineralization rate constant $\left(\mathrm{kg} \mathrm{ha}^{-1} \mathrm{day}^{-1}\right)$ and TF is temperature factor, according to Wade et al. (2002) and $S_{1 \_ \text {Miner }}$ is the soil moisture 


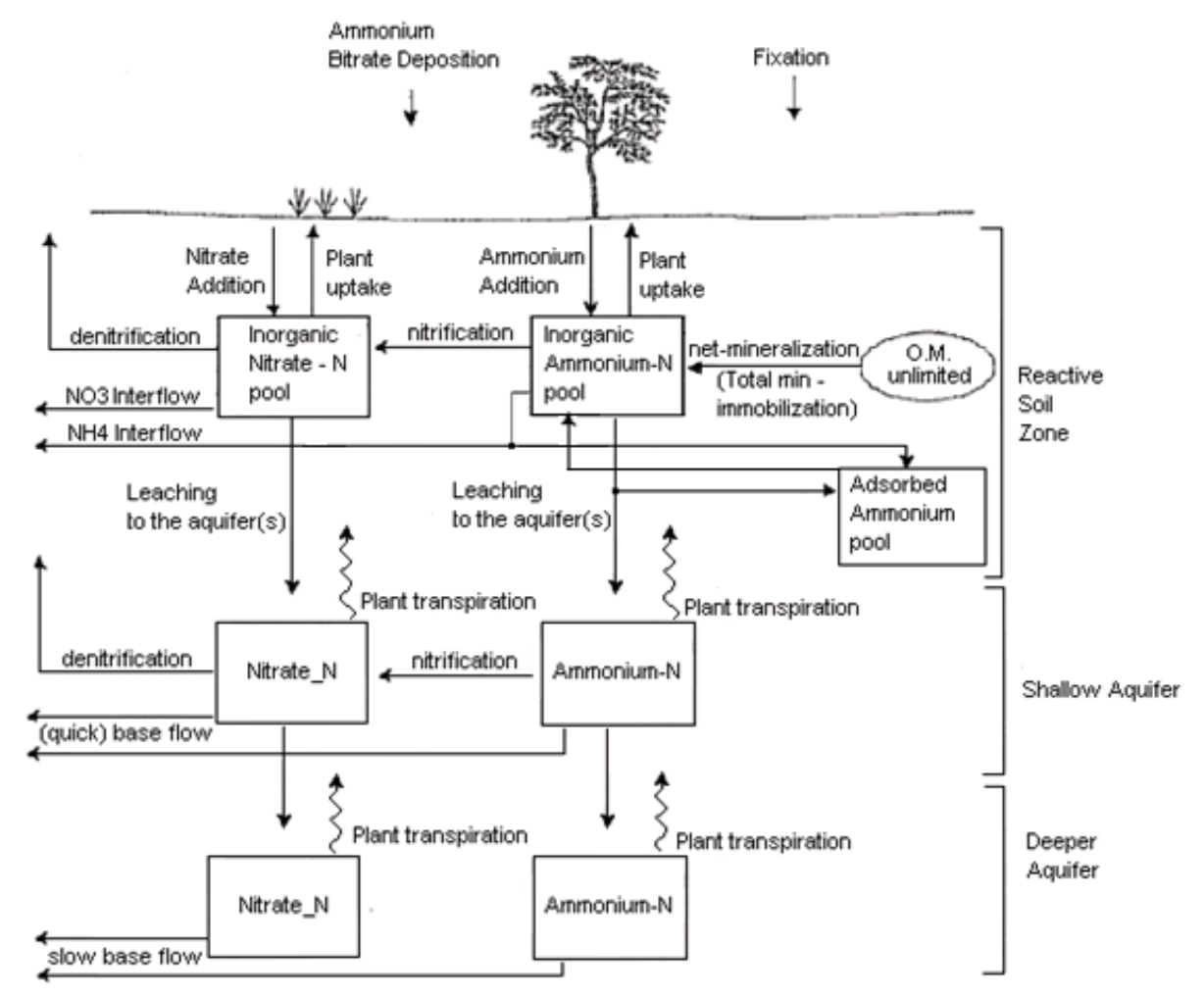

Fig. 2. Nitrogen cycle in the soil and aquifers systems for the LU4-N model (modified from Whitehead et al., 1998).

factor, which is calculated as follows:

$$
\begin{aligned}
& S_{1 \_ \text {Miner }}(t)=\frac{H_{1}(t)-\mathrm{IA}}{U_{\text {Miner }}} \text { if } 0 \leq H_{1}(t)-\mathrm{IA} \leq U_{\text {Miner }} \\
& \left(\leq H_{u}^{*}\right) S_{1 \_ \text {Miner }}(t)=1-\frac{\left(H_{1}(t)-\mathrm{IA}-U_{\text {Miner }}\right)}{\left(H_{u}^{*}-U_{\text {Miner }}\right)} \\
& \quad \text { if } U_{\text {Miner }}<H_{1}(t)-\mathrm{IA} \leq H_{u}^{*}
\end{aligned}
$$

where: $H_{1}$ is the actual static storage water content $(\mathrm{mm})$ and $H_{u}^{*}$ is the maximum static storage water content $(\mathrm{mm})$ (where the static tank represents water that can leave the catchment only by evapotranspiration); IA are the initial abstractions (interception and water detention in puddles) which were (approximately) estimated as $19 \mathrm{~mm} \mathrm{day}^{-1} ; t$ is the time step (day) and $U_{\text {Miner }}$ is the soil moisture threshold for mineralization $(\mathrm{mm})$, which is expressed as a percentage of $H_{u}^{*}$.

According to Eq. (2), the $S_{1 \_ \text {Miner factor has a triangular }}$ shape with a maximum value when the soil moisture content is equal to $U_{\text {Miner }}$. This is consistent with McIntyre et al. (2009), who found that mineralization is reduced under soil moisture content close to saturation, but increases under moderate soil moisture content. For the other soil nitrogen processes, the corresponding soil moisture factors are computed according the following general expression:

$$
\begin{aligned}
& S_{1 \_ \text {Process }}(t)=0 \quad \text { if } \quad 0 \leq H_{1}(t)-\mathrm{IA} \leq U_{\text {Process }} \\
& \left(\leq H_{u}^{*}\right) S_{1 \_ \text {Process }}(t)=\frac{\left(H_{1}(t)-\mathrm{IA}-U_{\text {Process }}\right)}{\left(H_{u}^{*}-U_{\text {Process }}\right)} \\
& \text { if } U_{\text {Process }}<H_{1}(t)-\mathrm{IA} \leq H_{u}^{*}
\end{aligned}
$$

where: $U_{\text {Process }}$ is the generic soil moisture threshold for the soil process included in the model (except mineralisation); $S_{1 \_ \text {Process }}$ is the soil moisture factor for any soil nitrogen process. Thus for any soil $\mathrm{N}$ process, except mineralization, a minimum soil moisture content is needed for the process to be activated.

The LU4-N model was then evolved to a simple semidistributed structure splitting the catchment into two Hydrological Representative Units (HRUs): (1) the riparian zone that represents approximately $0.5 \%$ of the total catchment area, corresponding to a part of the alluvial zone that goes along the edge of the river (Fig. 1); and (2) the rest of the catchment (hill-slope hereafter). In this way two different parameters sets were considered, one for each HRU. The LU4-R-N considers neither the spatial variability of the evapotranspiration nor that of the lithology. The LU4-R-N model requires 42 parameters to be calibrated, of which 11 for the rainfall-runoff model and 31 for the $\mathrm{N}$ sub-model (12 specific for each HRU and 7 common for the whole catchment) (Table 1). The aim with this model structure was to 
Table 1. Parameters considered in each of the three structures (LU4-N, LU4-R-N and SD4-R-N) and their effective values after calibration process.

\begin{tabular}{|c|c|c|c|c|c|c|c|c|c|}
\hline & \multirow[b]{2}{*}{ Parameters } & \multirow[b]{2}{*}{ Description } & \multirow{2}{*}{$\begin{array}{l}\text { LU4-N } \\
\text { Basin }\end{array}$} & \multicolumn{2}{|c|}{ LU4R-N } & \multicolumn{4}{|c|}{ SD4R-N } \\
\hline & & & & slope & Rip. Z & Leucogr. & Granod. & Schist & Rip. Z \\
\hline \multicolumn{10}{|c|}{ Nitrogen model calibrated parameters } \\
\hline 1 & $K_{\min }$ & $\begin{array}{l}\text { Hillsolpe mineralization rate } \\
{\left[\mathrm{Kg} \mathrm{ha}^{-1} \mathrm{day}^{-1}\right]}\end{array}$ & 0.51 & 0.51 & 3.5 & & 0.5 & & 3.3 \\
\hline 2 & $K_{\text {nitr }}$ & $\begin{array}{l}\text { Nitrification rate } \\
{\left[\text { day }^{-1}\right]}\end{array}$ & 1.0 & 0.6 & 1.0 & & 1.0 & & 2.2 \\
\hline 3 & $K_{\text {denitr }}$ & $\begin{array}{l}\text { Denitrification rate } \\
{\left[\text { day }^{-1}\right]}\end{array}$ & 0.1 & 0.08 & 1.8 & & 0.04 & & 1.17 \\
\hline 4 & $K_{\mathrm{imm}}$ & $\begin{array}{l}\text { Immobilization rate } \\
{\left[\text { day }^{-1}\right]}\end{array}$ & 0.15 & 0.1 & 0.01 & & 0.34 & & 0.53 \\
\hline 5 & $K_{\text {up } \mathrm{NO}_{3}}$ & $\begin{array}{l}\text { Nitrate plant uptake } \\
\text { rate }\left[\text { day }^{-1}\right]\end{array}$ & 50 & 2.04 & 2.04 & & 44.15 & & 63.04 \\
\hline 6 & $K_{\text {up NH}}$ & $\begin{array}{l}\text { Ammonium plant uptake } \\
\text { rate }\left[\text { day }^{-1}\right]\end{array}$ & 50 & 4.39 & 4.39 & & 8.28 & & 77.34 \\
\hline 7 & $K_{\text {denitr_aquif }}$ & $\begin{array}{l}\text { Shallow aquifer denitrification } \\
\text { rate }\left[\text { day }^{-1}\right]\end{array}$ & 0.06 & 0.08 & 0.04 & & 0.22 & & 0.11 \\
\hline 8 & $K_{\text {nitr_aquif }}$ & $\begin{array}{l}\text { Shallow aquifer nitrification } \\
\text { rate }\left[\text { day }^{-1}\right]\end{array}$ & 1.84 & 1.84 & 1.97 & & 0.97 & & 0.18 \\
\hline 9 & $K_{\text {ads }}$ & $\begin{array}{l}\text { Ammonium soil adsorption } \\
\text { rate }\left[\text { day }^{-1}\right]\end{array}$ & 0.88 & \multicolumn{2}{|c|}{0.88} & \multicolumn{4}{|c|}{0.82} \\
\hline 10 & $K_{\text {des }}$ & $\begin{array}{l}\text { Ammonium soil desorption } \\
\text { rate }\left[\text { day }^{-1}\right]\end{array}$ & 0.05 & \multicolumn{2}{|c|}{0.05} & \multicolumn{4}{|c|}{0.5} \\
\hline 11 & $U_{\min }$ & $\begin{array}{l}\text { Mineralization soil moisture } \\
\text { threshold }\left(\% \mathrm{Hu}^{*}\right)\end{array}$ & 42.9 & 42.9 & 36.8 & & 53.7 & & 22.9 \\
\hline 12 & $U_{\text {nitr }}$ & $\begin{array}{l}\text { Nitrification soil moisture } \\
\text { threshold }\left(\% \mathrm{Hu}^{*}\right)\end{array}$ & 50.9 & 50.9 & 34.0 & & 60.24 & & 34.0 \\
\hline 13 & $U_{\text {denitr }}$ & $\begin{array}{l}\text { Denitrification soil moisture } \\
\text { threshold }\left(\% \mathrm{Hu}^{*}\right)\end{array}$ & 80.0 & 70.0 & 67.0 & & 99.3 & & 98.1 \\
\hline 14 & $U_{\text {immob }}$ & $\begin{array}{l}\text { Immobilization soil moisture } \\
\text { threshold }\left(\% \mathrm{Hu}^{*}\right)\end{array}$ & 37.1 & 37.1 & 68.7 & & 98.3 & & 93.4 \\
\hline 15 & $C_{9}$ & $\begin{array}{l}\text { Maximum temperature } \\
\text { difference }\left({ }^{\circ} \mathrm{C}\right)\end{array}$ & 6.15 & \multicolumn{2}{|c|}{6.15} & \multicolumn{4}{|c|}{6.15} \\
\hline 16 & $\operatorname{MaxAds} \mathrm{NH}_{4}$ & $\begin{array}{l}\text { Daily max. } \mathrm{NH}_{4} \text { adsorption } \\
{\left[\mathrm{kg} \text { day }{ }^{-1} \mathrm{~km}^{-2}\right]}\end{array}$ & 14.5 & \multicolumn{2}{|c|}{14.5} & \multicolumn{4}{|c|}{36.14} \\
\hline 17 & $\operatorname{MaxUP} \mathrm{NH}_{4}$ & $\begin{array}{l}\text { Annual max. } \mathrm{NH}_{4} \text { uptake } \\
{\left[\mathrm{Kg} \mathrm{ha}^{-1} \mathrm{day}^{-1}\right]}\end{array}$ & 90.1 & \multicolumn{2}{|c|}{90.1} & \multicolumn{4}{|c|}{97.9} \\
\hline 18 & $\operatorname{Max} \mathrm{UP}_{\mathrm{NO}_{3}}(1)$ & $\begin{array}{l}\text { Annual max. } \mathrm{NO}_{3} \text { uptake } \\
{\left[\mathrm{Kg} \mathrm{ha}^{-1} \text { day }^{-1}\right]} \\
\text { (December, January and } \\
\text { February) }\end{array}$ & 21.6 & \multicolumn{2}{|c|}{21.6} & \multicolumn{4}{|c|}{18.5} \\
\hline 19 & $\operatorname{MaxUP} \mathrm{NO}_{3}(2)$ & $\begin{array}{l}\text { Annual max. } \mathrm{NO}_{3} \text { uptake } \\
{\left[\mathrm{Kg} \mathrm{ha}^{-1} \text { day }^{-1}\right]} \\
\text { (Rest of the year) }\end{array}$ & 118.0 & 118.0 & & & 55 & & 110 \\
\hline
\end{tabular}

analyze the possible effect of the riparian zone on nitrate release to the stream. The LU4-R hydrological model and the $\mathrm{N}$ sub-model were coupled following the scheme shown in Fig. 3. The hydrological conceptual scheme adopted for the semi-distributed model differs slightly from that published in Medici et al. (2008). In this case, part of the hill- slope discharge (corresponding to the area not drained by the four small reservoirs, which represents approximately $37 \%$ of the total catchment area) is routed through the riparian storage before reaching the stream channel (Fig. 3). This change does not affect the hydrology simulation considerably, but is thought to be relevant for simulating solute 


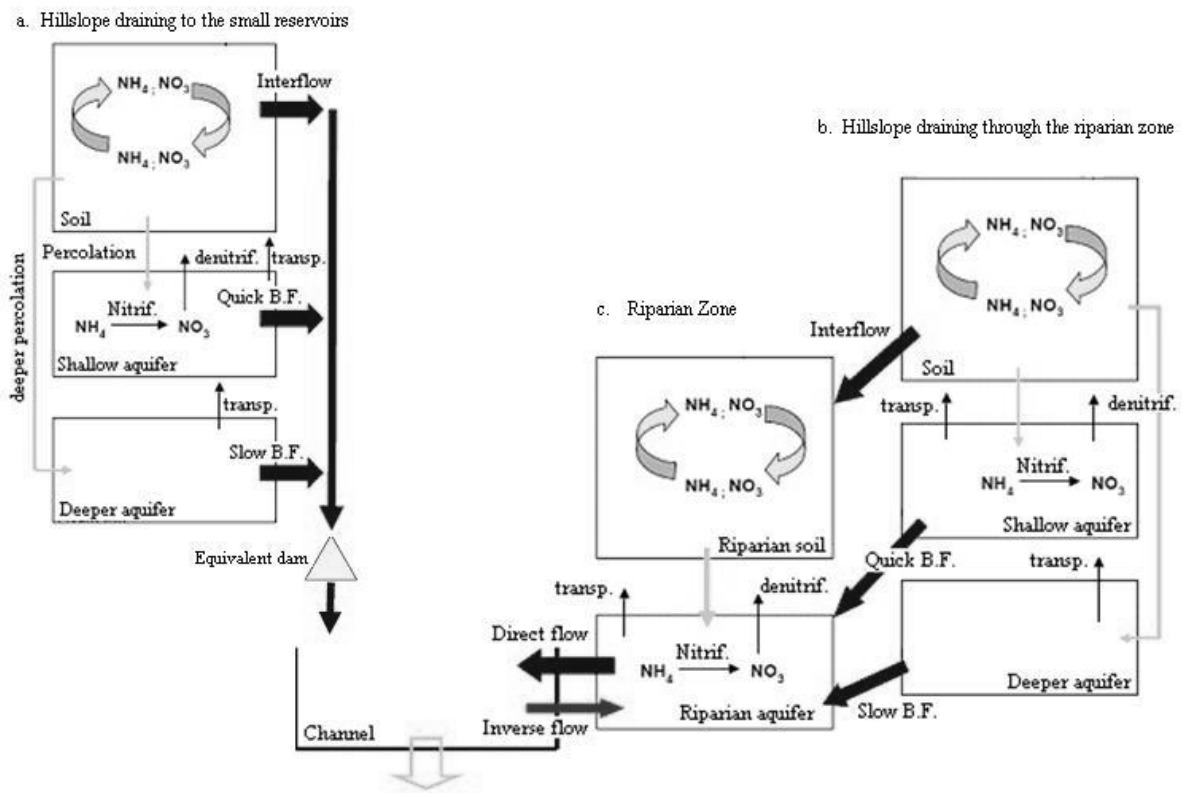

Fig. 3. LU4-R-N and SD4-R-N conceptual scheme, where (a) represents the part of the catchment that drains to the four small reservoirs located at the catchment; (b) represents the part of the catchment that drains through the riparian zone before reaching the stream channel and finally (c) represents the riparian zone which presents a bidirectional flow with the channel.

behaviour. We assumed that the main effect of the four reservoirs mainly was dilution on nitrate and ammonium concentration. In a next phase of development, the LU4-R-N was extended to include the spatial variation in evapotranspiration and lithology (SD4-R-N). As such, the catchment was divided into 4 HRUs: the three main catchment lithological units (leucogranite, granodiorite and sericitic schists, all together cited in this paper as hill-slope zone) and the riparian zone, as those used in the application of the SD4-R hydrological model (Medici et al., 2008). Thus, the PET spatial variability for the actual evapotranspiration computation was included taking into account the representative vegetation cover and the potential sunshine arriving to each lithological unit according to its representative aspect and surrounding relief. The parameterization of the 4-HRUs was done for the rainfall-runoff sub-model only; for the $\mathrm{N}$ sub-model, only the riparian and reminder of the catchment HRUs were considered for parameterization (Table 1). In this case, the total number of parameters to be calibrated for the hydrological model is 28 , while for the $\mathrm{N}$ model is still 31 as for the LU4-R-N model.

\section{Results}

The calibration period covers approximately three hydrological years from October 1999 to August 2002, while the temporal validation one considers the period from August 2002 to June 2003 (that means that the model was tested using a period of observed data different from the one used for the calibration process). Only nitrate concentrations were available for the temporal validation process. Parameters were optimized taking into account the Nash and Sutcliffe efficiency index $(E)$, the balance error in terms of observed and simulated global loads (BE) (where the term "global" refers to the whole calibration or validation period), the graphical fit between observed and simulated $\mathrm{N}$ time-series, the relative Root Mean Square Error (RMSE) index and the coefficient of determination $\left(r^{2}\right)$. The calibration was done by an automatic process, namely Evolver 4.0 for Excel (32-bit) and then by final manual adjustment of the parameters to check the behaviour of the model. For the LU4-N model the same parameters determined in the study by Medici et al. (2008) were adopted for the hydrology simulation, so therefore only the $19 \mathrm{~N}$-model parameters were calibrated in this study (Table 1). On the other hand, in the case of the semi-distributed models (LU4-R-N and SD4-R-N), the rainfall-runoff model was calibrated first and afterwards the $\mathrm{N}$ sub-model. Because of the different hydrological scheme adopted for this study, the parameters set for the hydrology slightly differed to that proposed in Medici et al. (2008) without representing any relevant change worthy of attention. The parameter values determined in the calibration of each of the three nitrogen sub-model structures are shown in Table 1. The goodnessof-fit measures for the calibration and validation periods are summarized in Tables 2 and 3, respectively. 
Table 2. Calibration goodness of fit indexes (from 13 October 1999 to 22 August 2002): the global and annual Nash index ( $E$; where $E=1$ is the optimum); the global balance volume errors (BE); the coefficient of determination $\left(r^{2}\right)$ (only shown when $p<0.01$ ) and the relative Root mean square error (Relative RMSE; where RMSE $=0$ is the optimum).

\begin{tabular}{lccccccccc}
\hline & \multicolumn{3}{c}{$\mathrm{LU}^{2}-\mathrm{N}$} & \multicolumn{3}{c}{$\mathrm{LU}_{4}-\mathrm{N}$} & \multicolumn{3}{c}{$\mathrm{SD}_{\mathrm{R}-\mathrm{N}}$} \\
Index & $Q$ & $\mathrm{NO}_{3}$ & $\mathrm{NH}_{4}$ & $Q$ & $\mathrm{NO}_{3}$ & $\mathrm{NH}_{4}$ & $Q$ & $\mathrm{NO}_{3}$ & $\mathrm{NH} 4$ \\
\hline$E_{\mathrm{TOT}}$ & 0.71 & 0.46 & $<0$ & 0.70 & 0.53 & $<0$ & 0.78 & 0.68 & $<0$ \\
$E_{1} \mathrm{yr}$ & 0.62 & $<0$ & $<0$ & 0.50 & 0.40 & 0.2 & 0.52 & 0.49 & 0.35 \\
$E_{2 \mathrm{yr}}$ & 0.62 & 0.47 & $<0$ & 0.61 & 0.43 & $<0$ & 0.43 & 0.57 & $<0$ \\
$E_{3 \mathrm{yr}}$ & 0.74 & 0.43 & $<0$ & 0.72 & 0.48 & $<0$ & 0.86 & 0.66 & $<0$ \\
$\mathrm{BE}_{\mathrm{TOT}} \%$ & -1.24 & -21.95 & -30.2 & -3.07 & -0.48 & -14.9 & 7.52 & -8.22 & 21.03 \\
$r^{2}$ & 0.77 & 0.5 & n.s. & 0.78 & 0.58 & 0.02 & 0.78 & 0.69 & 0.05 \\
Relative RMSE & 0.53 & 0.56 & 1.25 & 0.55 & 0.50 & 0.92 & 0.47 & 0.43 & 0.90 \\
\hline
\end{tabular}

\subsection{LU4-N calibration and validation results}

Observed nitrate and ammonium daily stream concentrations at Fuirosos and the corresponding simulated ones, obtained with the LU4-N model structure, are shown in Fig. 4a. The LU4-N model reproduced quite satisfactorily the observed daily nitrate concentrations for the calibration period ( $E=0.46)$. According to this model conceptualization, the main pathway controlling nitrate flushing is the flow derived from the shallow aquifer. As a matter of example, to reproduce the highest nitrate peak observed during March 2002 (Fig. 4a) the LU4-N model simulated, during the previous months, a huge accumulation of ammonium in soil that due to a significant rainfall event (almost $40 \mathrm{~mm} /$ day) percolated to the shallow aquifer where it was rapidly nitrified to nitrate. This nitrate rapidly reached the stream being transported with the water flowing from the shallow aquifer to the stream. The LU4-N model rarely generates interflow, which in general is associated with rainfall largest events $\left(>40 \mathrm{~mm} \mathrm{day}^{-1}\right)$ during the wet period, so it is the responsible for the nitrate flushing just in very few occasions. For example: the observed nitrate peak of the second year simulated (December 2000) it was a large simulated pulse of nitrification in the soil (almost $130 \mathrm{Kg} \mathrm{Km}^{-2}$ day $^{-1}$ ) that caused a major flush of nitrate transported with interflow. In fact, the model simulated an earlier ammonium increase in soil that was rapidly nitrified when the soil moisture content exceeded the threshold for nitrification as a result of a large rainfall event $\left(43 \mathrm{~mm} \mathrm{day}^{-1}\right)$ (Fig. 5). This nitrification pulse dynamic reproduced in terms of average annual loads a Mineralisation:Nitrification (M:N) ratio of 10:1, which is consistent with the results of Serrasolses et al. (1999). On the other hand, it is worthy to notice that the daily simulated $\mathrm{M}: \mathrm{N}$ ratio can achieve much higher values or it can also take values between zero and one (that means that nitrification overcomes mineralization), when a huge pick of nitrification takes place (Fig. 6). Concerning the simulation of streamwater ammonium concentrations, the LU4-N model could not
Table 3. Validation goodness of fit indexes (from 1 August 2002 to 30 June 2003): the global and annual Nash index ( $E$; where $E=1$ is the optimum); the global balance volume errors (BE); the coefficient of determination $\left(r^{2}\right)$ (only shown when $p<0.01$ ) and the relative Root mean square error (Relative RMSE; where RMSE $=0$ is the optimum).

\begin{tabular}{lcccccc}
\hline \multirow{2}{*}{ Index } & \multicolumn{2}{c}{ LU4-N } & \multicolumn{2}{c}{ LU4R-N } & \multicolumn{2}{c}{ SD4R-N } \\
& $Q$ & $\mathrm{NO}_{3}$ & $Q$ & $\mathrm{NO}_{3}$ & $Q$ & $\mathrm{NO}_{3}$ \\
\hline$E_{\text {TOT }}$ & 0.48 & $<0$ & 0.61 & 0.40 & 0.5 & 0.32 \\
BE & 28.37 & -30.2 & 24.17 & -6.0 & 47 & 7.12 \\
$r^{2}$ & 0.78 & 0.2 & 0.77 & 0.4 & 0.74 & 0.4 \\
Relative RMSE & 0.69 & 0.96 & 0.60 & 0.50 & 0.68 & 0.53 \\
\hline
\end{tabular}

reproduce the observations $(E<0)$ and the statistical relation between the simulated and observed data was not significant (Table 2). Despite the good results obtained for the calibration of the stream daily nitrate concentrations, the LU4-N model gave poor results for the validation period (Table 3 ). The model overestimated the nitrate concentration from $\mathrm{Au}-$ gust to October 2002, due to excessive nitrate amount carried by the base flow and the streamwater nitrate concentrations observed during late autumn and winter 2002-2003 were underestimated (Fig. 7a). A simple one-at-a-time perturbation sensitivity analysis highlighted that the mineralization related parameters $\left(K_{\min }\right.$ and $\left.U_{\min }\right)$, along with the maximum static storage water content $\left(H_{u}^{*}\right)$ and the maximum annual ammonium plant uptake (MaxUP $\left.\mathrm{NH}_{4}\right)$ had the major impact on the nitrate related objective functions. Ammonium soil adsorption rate $\left(K_{\text {ads }}\right)$ and the nitrification soil moisture threshold $\left(U_{\text {nitr }}\right)$ were also highlighted as quite sensitive parameters considering the ammonium related objective functions. 

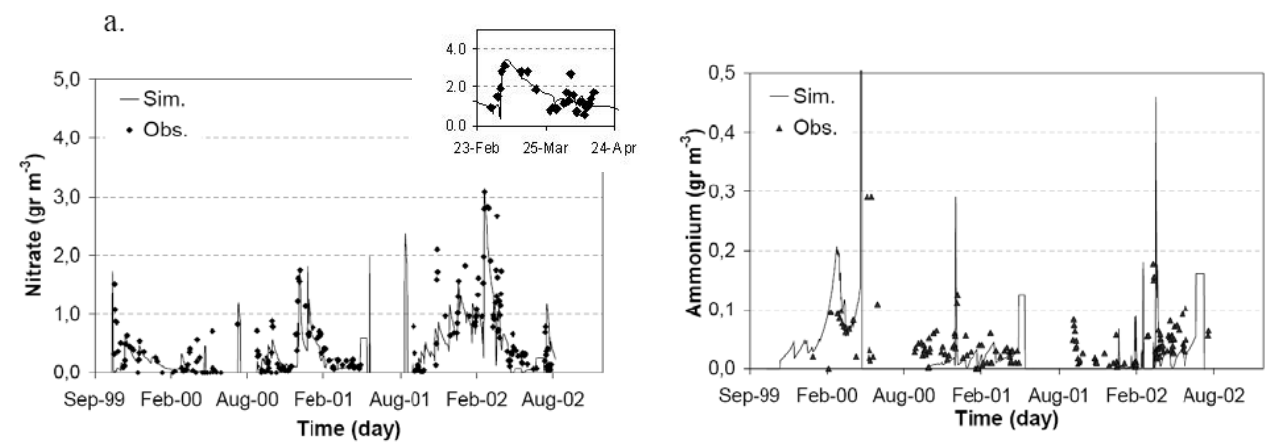

b.
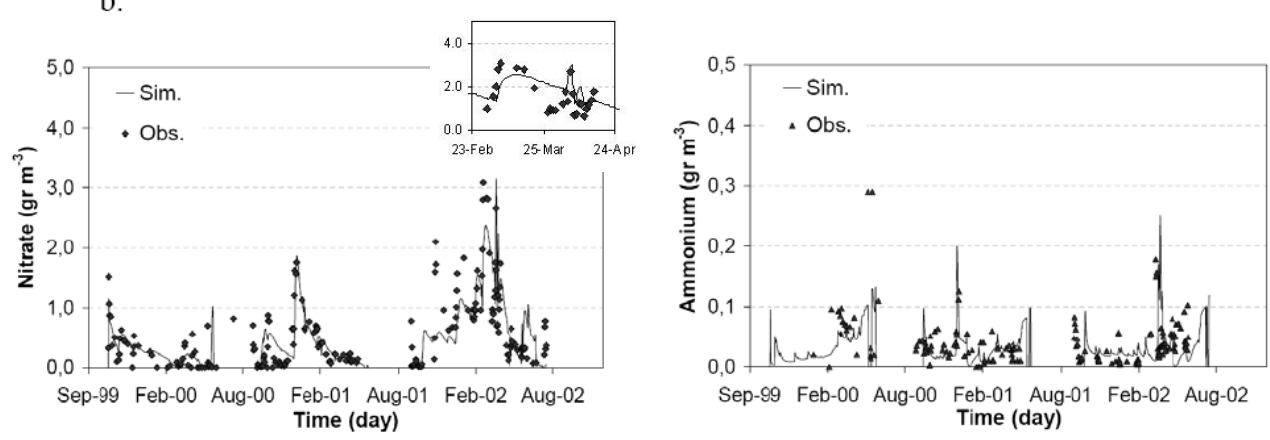

c.
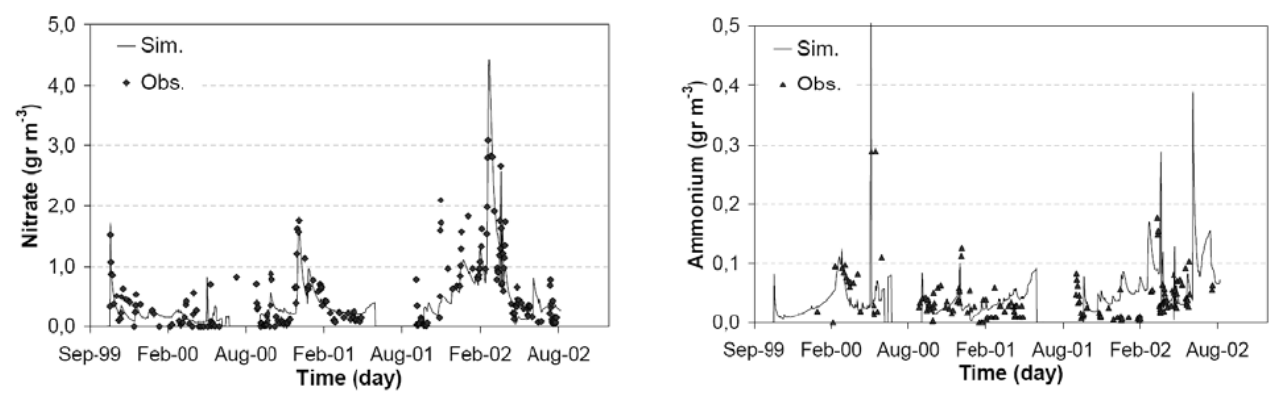

Fig. 4. Simulated and observed nitrate and ammonium $\left(\mathrm{gr} \mathrm{m}^{-3}\right.$ ) for the calibration period (1999-2002) with (a) LU4-N; (b) LU4-R-N (with 2 HRUs) and (c) SD4-R-N (with 4 HRUs).

\subsection{LU4-R-N calibration and validation results}

Observed nitrate and ammonium daily stream concentrations at Fuirosos and the corresponding simulated ones, obtained with the LU4-R-N model structure, are shown Fig. 4b. The obtained discharge efficiency and goodness indexes for the calibration period are similar to those obtained from the simulations done using the LU4-N model (Table 2). This occurs in part because the calibrated parameters for the hydrological components of the models are similar. Though, the nitrate simulation for the calibration period improved.

The global $E$ index for the daily nitrate concentration increased to 0.56, and the global BE error decreased to approximately $-15 \%$, despite the fact that the LU4-R-N model largely underestimated the highest nitrate concentration peak observed during March 2002 (Fig. 4b). The LU4-R-N model reproduced the nitrate concentration peak observed during April 2002 that was not simulated by the LU4-N model.

During this occasion, because of a large rainfall event (almost $64 \mathrm{~mm} \mathrm{day}^{-1}$ ) the two models could generate nitrate that washed from the soil with interflow at approximately the same rate. However, in the case of the LU4-R-N model, part of the interflow passed through the riparian zone soil (Fig. 3) mobilizing nitrate previously accumulated in this pool. It has to be noticed that in the riparian soil, the simulated mineralization process occurred at a significantly higher rate than in the hill-slope soil and the nitrification process followed more closely the pattern of simulated mineralization being activated more easily than in the hill-slope area (Fig. 8). Therefore, the simulated annual M:N ratio in the riparian zone was 


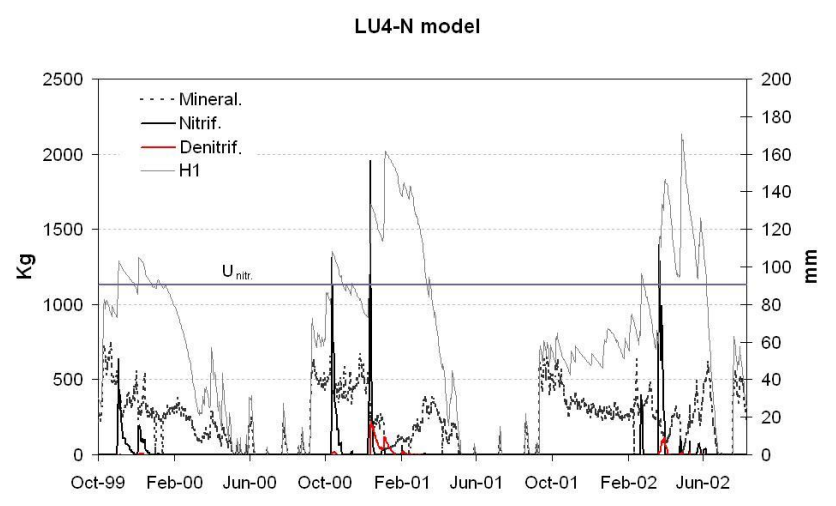

Fig. 5. Simulated soil moisture content $\left(H_{1}\right)$ and nitrification soil moisture threshold $\left(U_{\text {nitr }}\right)$ in $\mathrm{mm}$, plus mineralization, nitrification and denitrification processes $(\mathrm{kg})$ for the calibration period (19992002) with the LU4-N model.

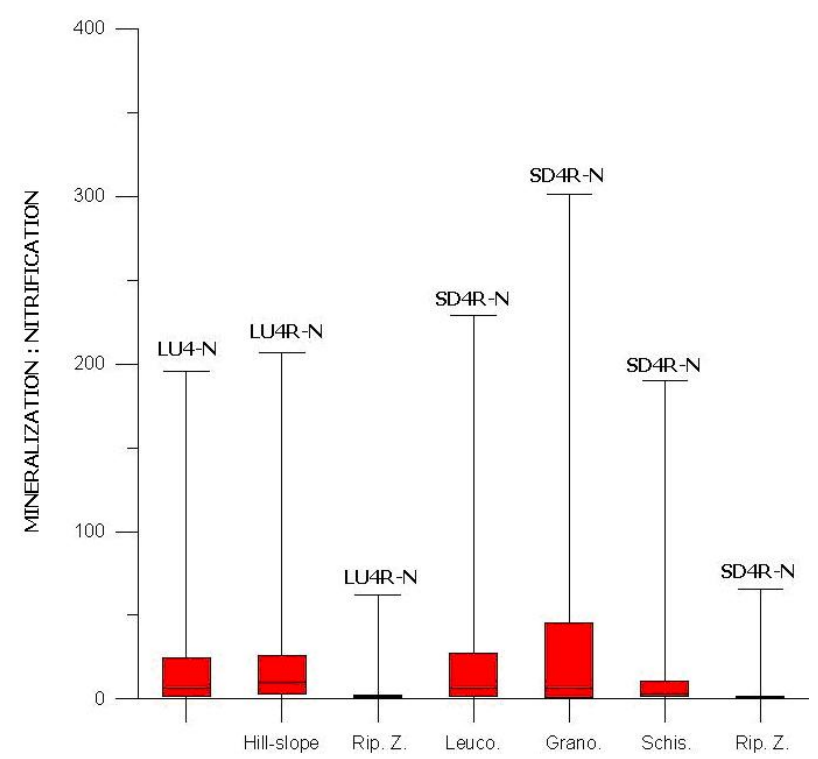

Fig. 6. Simulated Mineralization:Nitrification ratio (M:N) variation according to the different models structures and to each HRU considered.

almost 1:1 as well as the daily $\mathrm{M}: \mathrm{N}$ ratio, while in the hillslope zone the M:N ratio showed a higher variability as in the case of the lumped LU4-N model (Fig. 6). This dynamic allowed a significant amount of nitrate to be accumulated in the riparian soil, which was available to be rapidly flushed away by interflow derived from the hill-slope soil, as observed in April 2002.

The temporal validation process gave better results for the LU4-R-N model than for the LU4-N model (Table 3 and Fig. 7b). In particular, the introduction of the riparian zone allowed reproducing the nitrate concentration peak observed during November 2002 due to the same mechanism aforementioned (i.e., previous nitrate accumulation in the riparian
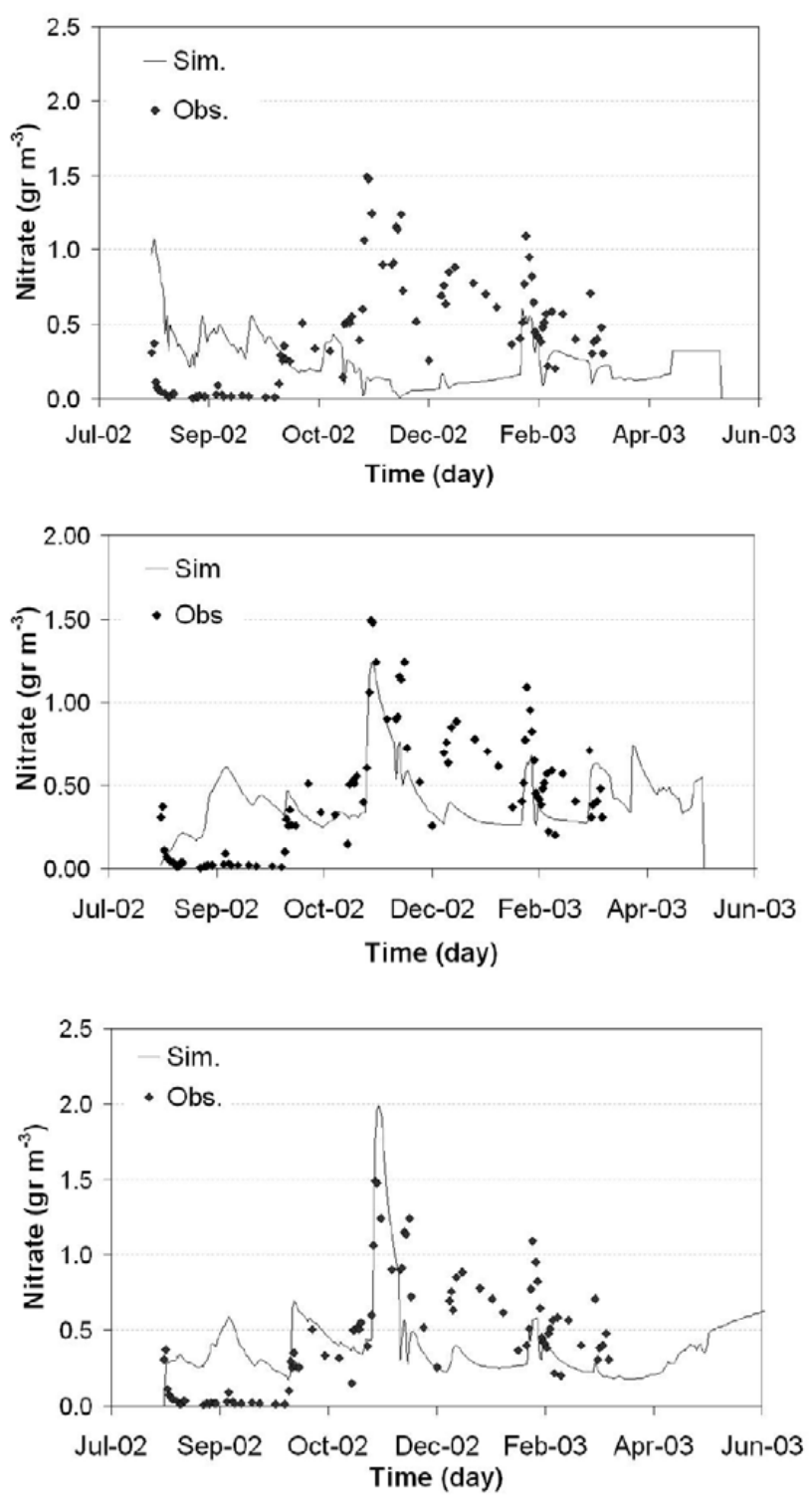

Fig. 7. Simulated and observed stream nitrate concentration $\left(\mathrm{gr} \mathrm{m}^{-3}\right.$ ) for the validation period (1999-2002) with (a) LU4-N; (b) LU4R-N (with 2 HRUs) and (c) SD4R-N (with 4 HRUs).

upper soil that is afterwards flushed away by interflow derived from the hill-slope soil).

Finally, the LU4-R-N model failed to reproduce the observed stream daily ammonium concentration. There was only a weak statistical relation between the observed and simulated streamwater ammonium concentrations $\left(r^{2}=\right.$ $0.02 ; p<0.1)$. The positive $E$ index for the first hydrological year (Table 2) represents a slight improvement from the result obtained for ammonium simulations with the LU4-N model.

A simple one-at-a-time perturbation sensitivity analysis highlighted that hillslope and riparian mineralization related parameters $\left(K_{\min }\right.$ and $\left.U_{\min }\right)$, maximum static storage water 
a.

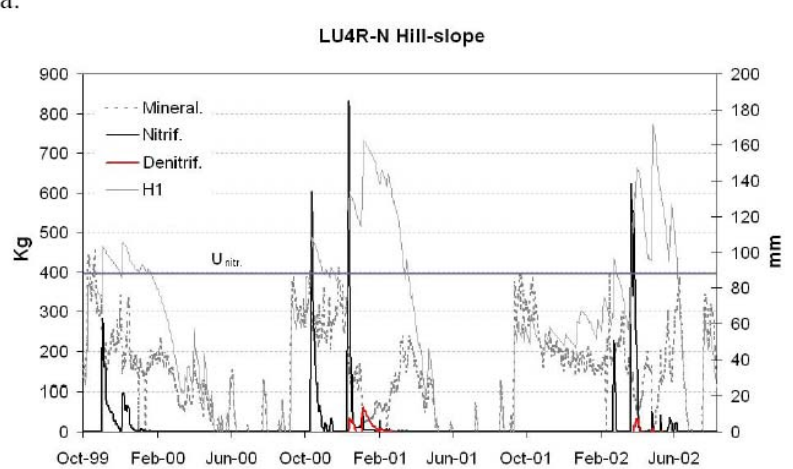

b.

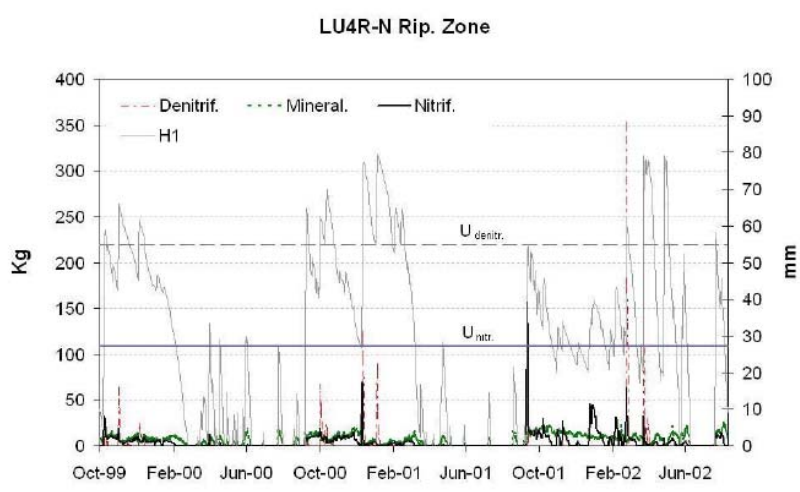

Fig. 8. Simulated soil moisture content $\left(H_{1}\right)$, nitrification soil moisture threshold $\left(U_{\text {nitr }}\right)$ and denitrification soil moisture threshold $\left(U_{\text {denitr }}\right)$ in mm, plus simulated mineralization, nitrification and denitrification processes $(\mathrm{kg}$ ) for the riparian zone (calibration period 1999-2002) with the LU4R-N model.

contents $\left(H_{u}^{*}\right)$, riparian denitrification related parameters $\left(K_{\text {denitr }}\right.$ and $\left.\mathrm{U}_{\text {denitr }}\right)$ and the maximum annual ammonium plant uptake (MaxUP $\mathrm{NH}_{4}$ ) had the major impact on the nitrate related objective functions. Ammonium soil adsorption rate $\left(K_{\text {ads }}\right)$ and the hillslope nitrification soil moisture threshold $\left(U_{\text {nitr }}\right)$ were also highlighted as quite sensitive parameters considering the ammonium related objective functions.

\subsection{SD4-R-N calibration and validation results}

Observed nitrate and ammonium daily stream concentrations at Fuirosos and the corresponding simulated ones, obtained with the SD4-R-N model structure, are shown Fig. 4c. The global discharge $E$ index for the calibration period was 0.78 , while for the first, second and third years respectively the $E$ index was $0.5,0.4$ and 0.86 (Table 2). The BE error was less than $8 \%$. Concerning the nitrate simulation, the $E$ index for the whole period was approximately 0.68 and the BE error less than $-9 \%$ (Table 2). Interestingly, this model structure could improve the simulation of the discharge peak flow observed on March 2002 (Fig. 9), which corresponded with the
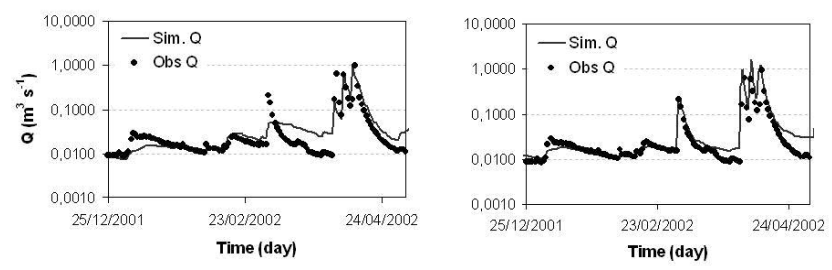

Fig. 9. Simulated and observed discharges $\left(\mathrm{m}^{3} \mathrm{~s}^{-1}\right)$ for the event of March 2002 obtained with: (a) the LU4-R-N model and (b) the SD4-R-N model.

highest nitrate concentration peak observed during the calibration period (Fig. 4). This discharge event can be classified as "intermediate flow" $\left(0.05 \mathrm{~m}^{3} \mathrm{~s}^{-1} \leq Q<1 \mathrm{~m}^{3} \mathrm{~s}^{-1}\right)$ according to Medici et al. (2008), which means that interflow was likely to have contributed along with the quick base flow. This suggestion is also supported by the slope steepness of the hydrograph recession. Neither the lumped LU4$\mathrm{N}$ model nor the semi-distributed LU4-R-N model could reproduce this discharge event because no interflow was generated in that instance and the only flow contributing to the discharge was the quick base flow. This improvement was reflected by the SD4-N-R model's ability to simulate satisfactorily the corresponding nitrate peak concentration which resulted in an $E$ index for the third year greater than 0.6 for the streamwater nitrate concentration simulations (Fig. $4 \mathrm{c}$ and Table 2).

Also in this case, the riparian zone was highlighted as a quite active zone where both the annual and daily $\mathrm{M}: \mathrm{N}$ ratio were most of the time quite close to $1: 1$, as in the case of the LU4-R-N model (Fig. 6). The M:N ratio behaviour for the leucogranite and granodiorite units was quite similar to the one obtained with the LU4-R-N model for the so called hillslope area, while in the scericitic schists unit the nitrification process could take place more easily than in the rest of the hill-slope giving in general smaller values for the M:N ratio (Figs. 5 and 10). The sericitic unit is mainly facing North and it is largely covered by a deciduous woodland (chestnut (Castanea sativa), hazel (Corylus avellana) and oak (Quercus pubescens) with well-developed litter layers which could bring about higher nitrification rates than in the granitic units.

Finally, concerning the ammonium daily concentrations, the SD4-R-N model could not reproduce satisfactorily the daily $\mathrm{NH}_{4}$ concentration for the calibration period (Fig. 4c, Table 2). The temporal validation results for this model structure are shown in Fig. 4c and Table 3. The $E$ index slightly decreased to 0.32 . Also in this case, a simple one-at-a-time perturbation sensitivity analysis highlighted in general the mineralization related parameters as the most sensitive, as well as the maximum static storage water contents of each HRUs $\left(H_{u}^{*}\right)$ and the annual maximum ammonium plant uptake $\left(\mathrm{MaxUP} \mathrm{NH}_{4}\right)$. Moreover, also the ammonium soil adsorption rate $\left(K_{\text {ads }}\right)$ and both hillslope and riparian zone nitrification soil moisture threshold $\left(U_{\text {nitr }}\right)$ were highlighted as 
Table 4. Nitrogen annual process rates.

\begin{tabular}{|c|c|c|c|c|}
\hline $\begin{array}{l}\mathrm{N} \\
\text { Processes }\end{array}$ & $\begin{array}{r}\text { Measured } \\
\text { values } \\
{\left[\mathrm{Kg} \mathrm{ha}^{-1} \mathrm{day}^{-1}\right]^{*}}\end{array}$ & $\begin{array}{r}\text { Sim. values } \\
{\left[\mathrm{Kg} \mathrm{ha}^{-1} \text { day }^{-1}\right]} \\
\text { LU4-N }\end{array}$ & $\begin{array}{r}\text { Sim. values } \\
{\left[\mathrm{Kg} \mathrm{ha}^{-1} \mathrm{day}^{-1}\right]} \\
\text { LU4R-N }\end{array}$ & $\begin{array}{r}\text { Sim. values } \\
{\left[\mathrm{Kg} \mathrm{ha}^{-1} \text { day }^{-1}\right]} \\
\text { SD4R-N }\end{array}$ \\
\hline Net mineralization & $32.4-80.1$ & 62.9 & 64.18 & 61.94 \\
\hline Net nitrification & $4.4-7.5$ & 6.19 & 7.83 & 8.84 \\
\hline Immobilization & 0.08 & 4.8 & 4.52 & 0.08 \\
\hline Nitrate uptake by vegetation & $10.3-58$ & 13.42 & 13.51 & 14.94 \\
\hline Ammonium uptake by vegetation & $53-80.5$ & 59.17 & 58.79 & 60.67 \\
\hline
\end{tabular}

* After Bernal et al., 2004.

quite influential parameters especially considering the ammonium related objective functions.

\section{Discussion}

The LU4-N model performance for the calibration period could be considered satisfactory in terms of daily nitrate concentration. However, the temporal validation process calls for caution when considering the result obtained, even if one year for the validation may not be sufficient to accept or reject a model conceptualization. Inspection of the validation results pointed out that the LU4-N model simulated adequately the discharge event observed during November 2002 (Medici et al., 2008), but was unable to reproduce the associated nitrate peak. In fact, there was insufficient nitrate left in soil to be washed into the stream by the interflow to create a peak in the streamwater nitrate concentrations.

Lowering the nitrate plant uptake from $50\left(\right.$ day $\left.^{-1}\right)$ to 0.3 $\left(\right.$ day $\left.^{-1}\right)$, which would be the maximum rate allowed to increase stream nitrate concentration during the validation period, increased the BE error for the calibration period to approximately $169 \%$ without significantly improving the model validation performance ( $E$ remained negative and $\mathrm{BE}$ increased to $75 \%$ ). Alternatively, the problem may be related to the nitrification dynamic; a more continuous nitrification process instead of a pulsed response could help to improve nitrate simulation during the validation period. However, problems arose when a permanent nitrification dynamic for the whole catchment was invoked. Specifically, it became impossible to simulate a $\mathrm{M}: \mathrm{N}$ ratio consistent with the one observed by Serrasolses (1999), unless the nitrification rate was kept extremely low but this resulted in a failure to represent the observed nitrate peaks. Also when considering a high mineralization rate that caused extreme high stream ammonium concentration, the annual immobilization rate became largely beyond the range expected from literature values (i.e., approximately $0.1 \mathrm{~kg} \mathrm{ha}^{-1} \mathrm{yr}^{-1}$ according to Bonilla (1990), after Bernal et al., 2004).

The impossibility of obtaining acceptable results with the LU4-N model for the validation process forced us to explore different model structures. To this end, several authors (Butturini et al., 2003; Bernal et al., 2007; McIntyre et al., 2009) noted the importance of the riparian zone as a "hot spot" for nitrate removal/production in Mediterranean catchments. It was also highlighted that the mechanism of mineralizationnitrification can be essentially different from the rest of the catchment due to the specific moisture condition and different organic matter that can be found there. Therefore, it was thought the role played by the riparian zone should have been taken into account, even if it is well know that adding model components and parameters to reproduce specific aspects of catchment behaviour does not necessarily lead to better results. Therefore, the lumped LU4-N model was evolved to a semi-distributed model that was applied considering firstly 2 HRUs (LU4-R-N) and then taking into account 4 HRUs (SD4-R-N), as previously explained.

According to the LU4-R-N and SD4-R-N models conceptualization, microbial processes in the hill-slope occur in pulses stimulated by soil moisture increasing after rain (Figs. 8 and 9), as it was for the whole catchment with the LU4-N model (Fig. 5). Namely, simulated nitrification, immobilisation and denitrification were allowed to occur only after exceeding their respective soil moisture thresholds (Table 1). This threshold mechanism gives rise in the hill-slope to pulses that are particularly significant for nitrification.

The LU4-R-N and SD4-R-N models, due to the threshold mechanism, reproduced in the hill-slope soil an annual average M:N ratio of approximately $8: 1$, which is consistent with the ratio (10:1) founded in other Mediterranean areas (e.g., Serrasolses et al., 1999), which was explained considering soil moisture limitation of nitrification. Interestingly, when considering the riparian zone alone the simulated M:N ratio decreased in both cases to almost 1:1 (Fig. 6). Supporting our simulations, Merrill (2006) found out that measured net mineralisation and net nitrification rates were similar in riparian zone ecosystem types. Moreover, it was found that in four of the five ecosystems considered in the study by Merrill (2006), net mineralization rates explained over $60 \%$ of the variation in net nitrification. This specific behaviour of the riparian soil allowed to easily accumulating nitrate that 

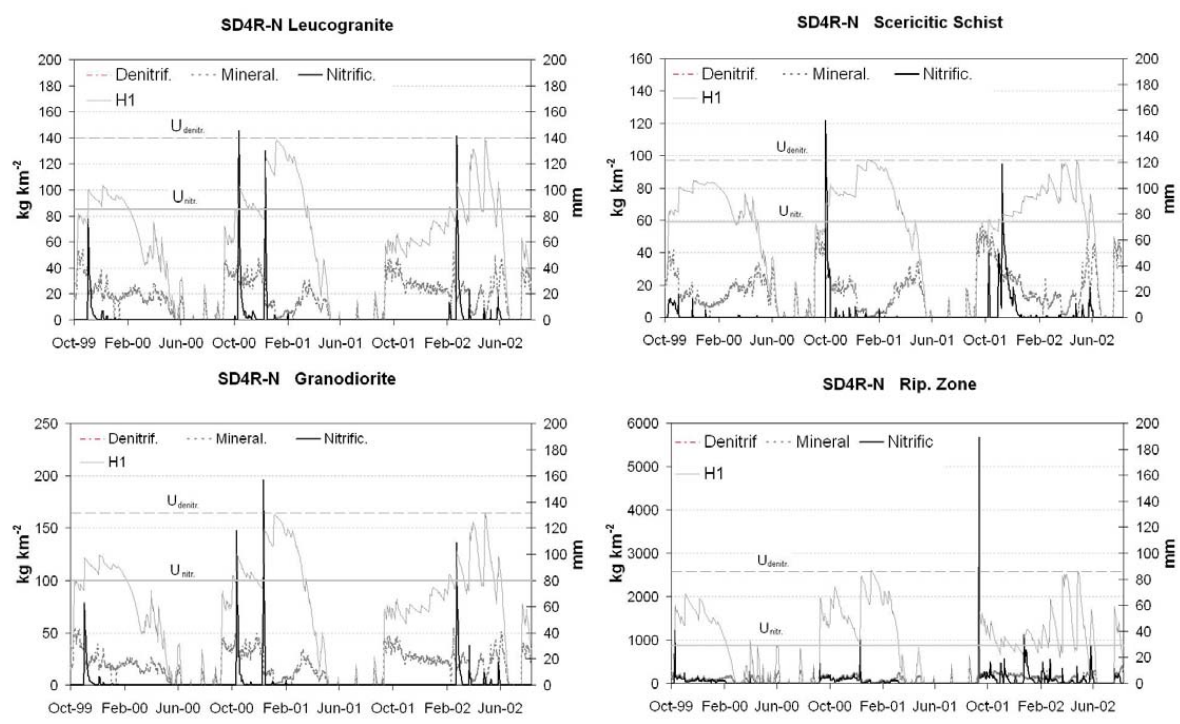

Fig. 10. Simulated soil moisture content $\left(H_{1}\right)$, nitrification soil moisture threshold $\left(U_{\text {nitr }}\right)$ and denitrification soil moisture threshold $\left(U_{\text {denitr }}\right)$ in $\mathrm{mm}$, plus simulated mineralization, nitrification and denitrification processes $\left(\mathrm{kg} \mathrm{km}^{-2}\right)$ for the riparian zone (calibration period 19992002) with the LU4R-N model.

could be washed away by the interflow derived from the hillslope causing significant increase in nitrate streamwater concentrations. Butturini et al. (2003) previously pointed out the unsaturated riparian soil layer at Fuirosos as a possible source of nitrate. In this study, it was observed that the rise of the local riparian groundwater table, after the summer drought, resulted in the rapid flushing of nitrate stored in the soil during the long dry period. Our results suggested also a higher mineralization rate in the riparian area than in the rest of the catchment. A possible explanation for that, may be that the major tree species at the hill-slope of Fuirosos are perennial cork oak (Quercus suber) and pine (Pinus halepensis and Pinus pinaster), therefore the mineralization rates are expected to be low as a consequence of allelopathic compounds leached from plants and the quality of sclerophyllous leaf (Gallardo and Merino, 1992; Castaldi et al., 2002). The stream channel is flanked by a well-developed riparian area where alder (Alnus glutionosa) - a tree species with high quality litter, and exotic plane tree (Platanus acerifolia) predominates, allowing for higher decomposition and mineralization rates of litter accumulated on the stream bed and stream edge zone. Moreover, Acuña et al. (2007) observed that in the Fuirosos stream, leaf fall may extend from late summer to autumn (August to November) during dry years, due to hydrologic stress. Therefore, large inputs of organic matter accumulate on the streambed and riparian zone may fuel heterotrophic activity during the transition and wet periods (Von Schiller et al., 2008). Simulated mineralization was highest immediately after the summer drought period, when the soil moisture content was approximately $50 \%$ or less of the maximum soil static water content. This is consistent with the study of McIntyre et al. (2009) which noted that, for a semi-arid intermittent stream, mineralization would be reduced under soil moisture conditions close to saturation, while it would increase under moderate saturation. Other authors observed a high rate of humus decomposition and rapid mineralization following rewetting of dry soils and it was also observed that soils subject to wetting and drying cycles, release more nitrogen than continuously moist soil (Birch, 1964; Dick et al., 2005; Rey et al., 2005). Bernal et al. (2005) observed, at Fuirosos, that mineralization activity existed in the mineral soil and/or in the stream channel particularly during the transition period from dry to wet conditions and in a previous study performed in the soil of the riparian area of Fuirosos, Bernal et al. (2003) reported the highest mineralization rates in autumn.

Interestingly, the SD4-R-N model reproduced a huge pulse of nitrification in the riparian soil just after the summer drought 2001 because of a sudden increase in soil moisture content due to the reverse flux (that is water flowing from the stream to the riparian zone), which is characteristic of arid and semi-arid areas (Fig. 9). This is consistent with Butturini et al. (2003) that pointed out the reverse flux as a possible mechanism responsible for nitrate release in the riparian zone.

All the model structures considered included denitrification and nitrification in the shallow aquifer. This was necessary to represent the nitrate behaviour. These processes controlled the rate of reduction in the streamwater nitrate and ammonium concentrations during base flow conditions. This is consistent with previous studies of biogeochemical activities in the unsaturated zone of weathered granite (Legout et al., 2005) which demonstrated potential for bacterial activity and biogeochemical reaction in the lower soil horizons 
associated with lower carbon content. In particular, Legout et al. (2005) suggested that both nitrification and denitrification are likely to take place in the unsaturated weathered granite below the soil organic horizon. The denitrification process occurring in the riparian groundwater was especially relevant for the SD4-R-N model (Fig. 11), while for the LU4-R-N model denitrification occurred mainly in the riparian upper soil (Fig. 8). In our model the riparian interflow eventually percolates to the local riparian aquifer due to the extremely low slope in this catchment area and thus, it is nearly impossible to distinguish between soil and aquifer riparian denitrification (Fig. 3). Nonetheless, our results highlighted that the denitrification process in the riparian zone is a key mechanism to the reduction of groundwater nitrate in particular during the wettest period of the year. This is consistent with previous studies in Mediterranean areas (Peterjohn and Correl, 1984; Butturini et al., 2003; Rassam et al., 2006; and Bernal et al., 2007).

Finally, none of the considered models could reproduce satisfactorily the daily stream ammonium concentration, which was low even during precipitation events. The observed stream daily ammonium concentration presents an erratic behaviour and extremely low values, which do not increase even during precipitation events. In annual terms, the relative contribution of nitrogen forms to the total catchment annual export is $57 \%, 35 \%$ and $8 \%$ as $\mathrm{NO}_{3}-\mathrm{N}$, DON and $\mathrm{NH}_{4}-\mathrm{N}$ respectively (Bernal et al., 2005). Moreover, the standard deviation of the chemical water analysis procedure adopted is approximately $0.02 \mathrm{mg} \mathrm{N} / 1$ (Hach Company, 1992. Water Analysis Handbook, 2nd ed. Hach Company, Loveland, Co.), which has the same magnitude of most observed daily ammonium concentrations. Thus, low ammonium concentrations which are not linked to flow as strongly as for nitrate are difficult to simulate satisfactorily. Nevertheless, the models could represent at least the ammonium general trend and order of magnitude, which taking into account its erratic behaviour it can be considered an acceptable result. In particular, differently from the INCA-N model, they did not simulate ammonium leaching during storm flow because we included the adsorption/desorption mechanism in the soil compartment improving its simulation.

\section{Conclusions}

The aim of this study was to improve our understanding of the main processes that govern the inorganic nitrogen fate and losses in Mediterranean catchments by means of mathematical modelling. The results highlighted that in those ecosystems a pulse dynamic for most of the soil biological processes, related with the rainfall pattern occurs as previously suggested by Schiwinning (2004b). We reproduced this pulse dynamic by introducing a moisture threshold for each simulated soil-biological process. The concept of response thresholds is recurrent in the ecology of arid/semi-

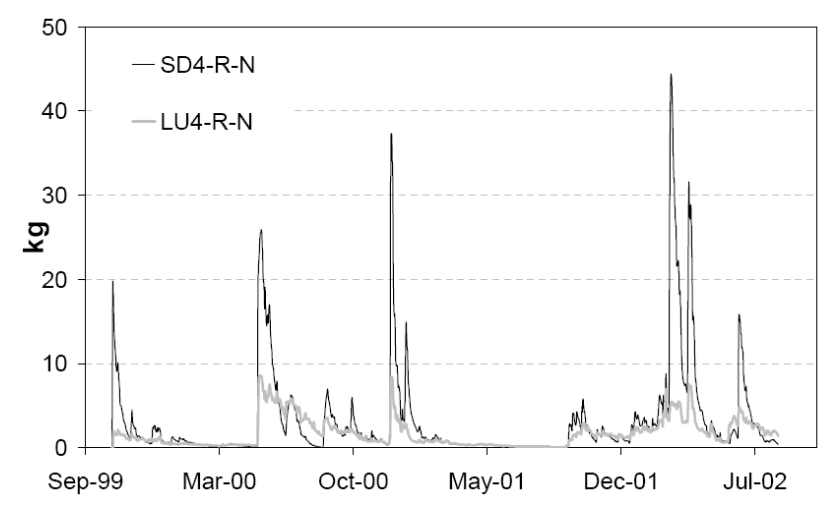

Fig. 11. Simulated denitrification process $(\mathrm{kg})$ in the riparian local aquifer with the LU4-R-N and SD4-R-N models.

arid systems (Beatly, 1974), and it has been used to explain the decoupling of nutrient gain and losses mechanisms (Schwinninng et al., 2004). Our simulations suggested that nitrification shows a pulse dynamic in the hillslope soil, while it occurs more continuously in the riparian soil, which together with the interflow flushing effect can give rise to important stream nitrate concentration peaks during some periods of the year. These results point towards the riparian upper soil as a possible source of nitrate in this type of ecosystems, consistently with that observed in previous empirical studies (e.g., Butturini et al., 2003). Interestingly, the model reproduced by means of calibration the so-called "Birch effect", which implies higher mineralization rate just after the summer drought. Finally, the results indicate the importance of the nitrification and denitrification processes in the unsaturated weathered granite below the soil organic horizon. The LU4-R-N and the SD4-R-N semi-distributed models could be calibrated to simulate flow and nitrate dynamic in Fuirosos and gave acceptable result for the temporal validation process. This suggests that the key processes controlling flow and nitrate behaviour are included within these models conceptual schemes and their mathematical representation seems reasonable.

Further work is needed to develop better simulations of ammonium storage and transport in the catchment and the link between organic- $\mathrm{N}$ and ammonium. In particular, a better understanding of the forms and quantities of organic-N is required. The three models described in the paper take into account the mineralization process in a very simplified way, considering the organic matter as unlimited and without distinguish among different kind of organic matter, which may have certain influence on the ammonium simulation results. It is known that the mass of ammonium is influenced by organic matter temporal variability and availability. However, a more complex description of this key process might increase dramatically the parameters to be calibrated introducing more uncertainty into the model. Finally, it has to be highlight that the models developed do not include any 
in-stream processes yet, which may be important in controlling the instream ammonium concentrations (von Schiller D. et al., 2008).

Acknowledgements. This study was supported by a Formación de Personal Investigador (FPI) grant and founds provided by the Generalitat Valenciana, Conselleria d'Educació and by the Ministerio de Educación Español (MEC) (projects: GCL2007-60144/HID; CGL2005-06219/HID CGL2008-03076-E/BTE).

Edited by: A. Guadagnini

\section{References}

Acuña, V., Giorgi, A., Muñoz, I., Sabater, F., and Sabater, S.: Metereological and riparian influences on organic matter dynamics in a forested Mediterranean stream, J. N. Am. Benthol. Soc., 26, 54-69, 2007.

Arheimer, B., Andersson, L., and Lepistö, A.: Variation of nitrogen concentration in forest streams. Influences of flow, seasonality and catchment characteristics, J. Hydrol., 179, 281-304, 1996.

Austin, A. T., Yahdjian, L., Stark, J. M., Belnap, J., Porporato, A., Norton, U., Ravetta, D. A., and Schaeffer, S. M: Water pulses and biogeochemical cycles in arid and semi-arid ecosystems, Oecologia, 141, 221-235, 2004.

Ávila, A., Bonilla, D., Rodá, F., Piñol, J., and Neal, C.: Soil water chemistry in a holm oak (Quercus ilex) forest: inteferences on biogeochemical processes for a montane Mediterranean area, J. Hydrol., 166, 15-35, 1995.

Beatley J. C.: Phenological events and their environmental triggers in Mojave-Desert, Ecosyst. Ecol., 55, 856-863, 1974.

Bernal, S., Butturini, A., Nin, E., Sabater, F., and Sabater, S.: Leaf litter dynamics and nitrous oxide emission in a Mediterranean riparian forest: implications for soil nitrogen dynamics, J. Environ. Qual., 32, 191-197, 2003.

Bernal, S., Butturini, A., Riera, J. L., Vázquez, E., and Sabater, F.: Calibration of the INCA model in a Mediterranean forested catchment: the effect of hydrological inter-annual variability in an intermittent stream, Hydrol. Earth Syst. Sci., 8, 729-741, 2004,

http://www.hydrol-earth-syst-sci.net/8/729/2004/.

Bernal, S., Butturini, A., and Sabater, F.: Seasonal variation of dissolved nitrogen and DOC:DON ratios in an intermittent Mediterranean stream, Biogeochemistry, 75, 351-372, 2005.

Bernal, S., Sabater, F., Butturini, A., Nin, E., and Sabater, S.: Factors limiting denitrification in a Mediterranean riparian forest, Soil Biol. Biochem., 39, 2685-2688, 2007.

Birch, H. F.: Further observations on humus decomposition and nitrification, Plant Soil, 11, 262-286, 1959.

Birch, H. F.: Nitrification in soil after different period of dryness, Plant Soil, 12, 81-96, 1960.

Birch, H. F.: Mineralization of plant nitrogen following alternate wet and dry conditions, Plant Soil, 12, 81-96, 1964.

Butturini, A., Bernal, S., Nin, E., Hellin, C., Rivero, L., Sabater, S., and Sabater, F.: Influence of the stream groundwater hydrology on nitrate concentration in unsaturated riparian area bounded by an intermittent Mediterranean stream, Water Resour. Res., 39(4), 1110, doi:10.1029/2001WR001260, 2003.
Castaldi, S. and Aragosa, D.: Factors influencing nitrification and denitrification variability in a natural and fire-disturbed Mediterranean shrubland, Biol. Fert. Soils, 36, 418-425, 2002.

Chapman, P. J., Edwards, A. C., and Cresser M. S.: The nitrogen composition of streams in upland Scotland: some regional seasonal differences, Sci. Total Environ., 265, 65-83, 2001.

Chu, Y., Salles, C., Cernesson, F., Perrin, J. L., and Tournoud, M. G.: Nutrient load modelling during floods in intermittent rivers: An operational approach, Environ. Modell. Softw., 23, 768-781, 2008.

Dick, J., Skiba, U., Munro, R., and Deans, D.: Effect of N-fixing trees and crops on $\mathrm{NO}$ and $\mathrm{N}_{2} \mathrm{O}$ emissions from Senegal soils, J. Biogeogr., 33, 416-423, 2005.

Gallardo, A. and Merino, J.: Nitrogen immobilization in leaf litter at two Mediterranean ecosystems of SW Spain, Soil Biol Biochem., 30, 1349-1358, 1992.

Gallart, F., Llorens, P., Latron, J., and Regüés, D.: Hydrological processes and their seasonal controls in a small Mediterranean mountain catchment in the Pyrenees, Hydrol. Earth Syst. Sci., 6, 527-537, 2002, http://www.hydrol-earth-syst-sci.net/6/527/2002/.

Gelfand, I. and Yakir, D.: Influence of nitrite accumulation in association with seasonal patternts and mineralization of soil nitrogen in a semi-arid pine forest, Soil Biol Biochem., 40(2), 415-424, 2008.

Green, P. A., Vörösmarty, C. J., Meybeck, M., Galloway, J. N., Peterson, B. J., and Boyer, E. W.: Pre-industrial and contemporary fluxes through rivers: a global assessment based on typology, Biogeochemistry, 68, 71-105, 2004.

Heckathorn S. A. and Delucia E. H.: Ammonia volatilization during drought in perennial C4 grasses of tallgrass prairie, Oecologia, 101, 361-365, 1995.

Hedin, L. O., Armesto, J. J., and Johnson, A. H.: Patterns of nutrients loss from unpolluted, old-growth temperature forests. Evaluation of biogeochemical theory, Ecology, 76, 493-509, 1995.

Jarvis, P., Rey, A., Petsikos, C., Wingte, L., Rayment, M., Pereira, J., Banza, J., David, J., Miglietta, F., Borghetti, M., Manca, G., And Valentini, R.: Drying and wetting of Mediterranean soils stimulates decomposition and carbon dioxide emission: the "Birch effect", Tree Physiol., 27, 929-940, 2007.

Legout, C., Molenat, J., Lefebvre, S., Marmonier, P., and Aquilina, L.: Investigation of biogechemical activities in the soil and unsaturated zone of weathered granite, Biogeochemistry, 75, 329-350, 2005.

McIntyre, R., Adams, M., Ford, D., and Grierson, F.: Rewetting and litter addition influence mineralisation and microbial communities in soils form a semi-arid intermittent stream, Soil Biol Biochem., 41, 92-101, 2009.

Medici, C., Butturini, A., Bernal, S., Vázquez, E., Sabater, F., Vélez, J. I., and Francés, F.: Modelling the non-linear hydrological behaviour of a small Mediterranean forested catchment, Hydrol. Process., 22, 3814-3828, 2008.

Merrill A. G. and Benning T. L.: Ecosystem type differences in nitrogen process rates and controls in the riparian zone of a montane landscape, Forest Ecol. Manag., 222, 145-161, 2006.

Mummey, D. L., Smith, J. L., and Bolton, H. J.: Nitrous oxide flux from a shrub-steppe ecosystem: sources and regulation, Soil Biol Biochem., 26, 279-286, 1994.

Ocampo, C. J., Oldham, C. E., and Sivapalan, M.: Nitrate 
attenuation in agricultural catchments: shifting balances between transport and reaction, Water Resour. Res., 42, W01408, doi:10.1029/2004WR003773, 2006.

Peterjohn, W. T. and Schlesinger, W. H.: Factors controlling denitrification in a Chihuahuan desert ecosystem, Soil Sci. Soc. Am. J., 55, 1694-1701, 1991.

Peterjohn W. T. and Correll D. L.: Nutrient dynamics in an agricultural watershed: observations on the role of the riparian forest, Ecology, 65, 1466-1475, 1984.

Rassam, D. W., Fellows, C. S., De Hayr, R., Hunter, H., and Bloesch, P.: The hydrology of riparian buffer zones: two case studies in an ephemeral and perennial stream, J. Hydrol., 325, 308-324, 2006.

Rey, A., Petsikos, C., Jarvis, P. G., and Grace, J.: Effect of temperature and moisture on rates of carbon mineralization in a Mediterranean oak forest soil under controlled and field conditions, Eur. J. Soil. Sci., 56, 589-599, 2005.

Reynolds, J. F., Kemp, P. R., Ogle, K., and Fernández, R. J.: Modifying the "pulse-reserve" paradigm for deserts of North America: precipitation pulses, soil water, and plant responses, Oecologia, 141, 194-210, 2004.

Schlesinger, W. H., Reckhow, K. H., and Bernhardt, E. S.: Global Change: The nitrogen cycle and rivers, Water Resour. Res., 42, W03S06, doi:10.1029/2005WR004300, 2006.

Schwinning, S. and Sala ,E. O.: Hierarchy of responses to resource pulses in arid and semi-arid ecosystems, Oecologia, 141, 211220, 2004a.

Schwinning, S., Sala, O. E., Loik, M. E., and Ehleringer J. R.: Thresholds, memory, and seasonality: understanding pulse dynamics in arid/semi-arid ecosytems, Oecologia, 141,: 191-193, 2004b.

Serrasolses, I., Diego, V., and Bomilla, D.: Soil nitrogen dynamics, in: Ecological of Mediterranean evergreen oak forests, edited by: Roda, F., Ecological Studies 137, Springer, Berlin, Germany, 1999.

Stark, J. M., Smart, D. M., Hart, S. C., and Haubensak, K. A.: Regulation of nitrite oxide emissions form forest and rangeland soils of western North America, Ecology, 83, 2278-2292, 2002.
Stieglitz, M., Shaman, J., McNamara, J., Engel, V., Shanley, J., and Kling, G. W.: An approach to understanding hydrological connectivity on the hillslope and the implications for nutrient transport, Global Biogeochem. Cy., 17, 1105, doi:10.1029/2003GB002041, 2003.

Van Gestel, M., Merckx, R., and Vlassak, K.: Microbial biomass responses tos oil drying and rewetting: the fate of fast- and slowgrowing microorganismo in soils from different climates, Soil Biol Biochem., 25, 109-123, 1993.

Vitousek, P. M., Naylor, R., Crews, T., David, M. B., Drinkwater, L. E., Holland, E., Johnes, P. J., Katzenberger, J., Martinelli, L. A., Matson, P. A., Nziguheba, G., Ojima, D., Palm, C. A., Robertson, G. P., Sanchez, P. A., Townsend, A. R., and Zhang, F. S.: Nutrient imbalances in Agricultural Development, Science, 324, 5937, 1519-1520, 2009.

Von Schiller, D., Martí, E., Riera, J. L., Ribot, M., Argerich, A., Fonollá, P., and Sabater, F.: Inter-annual, annual and seasonal variation of $\mathrm{P}$ and $\mathrm{N}$ retention ina perennial and an intermmitent stream, Ecosystems, 11, 670-687, doi:10.1007/s10021-0089150-3, 2008.

Wade, A. J., Durand, P., Beaujouan, V., Wessel, W. W., Raat, K. J., Whitehead, P. G., Butterfield, D., Rankinen, K., and Lepisto, A.: A nitrogen model for European catchments: INCA, new model structure and equations, Hydrol. Earth Syst. Sci., 6, 559-582, 2002, http://www.hydrol-earth-syst-sci.net/6/559/2002/.

Wade, A. J., Neal, C., Butterfield, D., and Futter, M. N.: Assessing nitrogen dynamics in European ecosystems, integrating measurement and modelling: conclusions, Hydrol. Earth Syst. Sci., 8, 846-857, 2004, http://www.hydrol-earth-syst-sci.net/8/846/2004/.

Whitehead, P. G., Wilson, P. G., and Butterfiled, D.: A semidistributed Nitrogen Model for Multiple Source Assessments in Catchments (INCA): Part 1 - Model structure and Process Equations, Sci. Total Environ., 201/211, 547-558, 1998. 